\title{
○ \\ Image and Text in Conceptual Art
}

Critical Operations in Context

Eve Kalyva

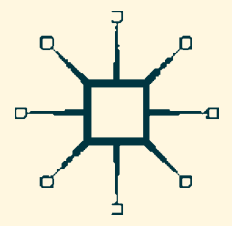


Eve Kalyva

\section{Image and Text \\ in Conceptual Art}

Critical Operations in Context

palgrave
macmillan 


\section{Contents}

1 Introduction 1

1.1 Why Language? 2

1.2 About This Book 8

References 14

2 Parallels Between Art and Language 15

2.1 Opening Remarks $\quad 15$

2.2 From Expression Theory to the Institutional

2.2.1 Logical Problems with Expression Theory 17

2.2.2 Towards an Institutional Theory of Art 19

2.3 Art as a Social Phenomenon. Semiotics and Ideology 23

2.3.1 A Semiotics of Visual Culture $\quad 25$

2.3.2 A Social History of Art 29

2.4 Art Systems and the Art Historical Discourse 30

2.5 New Perspectives from Socio-Linguistics:

2.6 Closing Remarks $\quad 36$

References 38

3 The Performative Gesture of Image and Text Juxtapositions 43

3.1 Opening Remarks 43

3.2 Speech Act Theory 46 
3.3 Staging the Act: Keith Arnatt's Art as an Act of Retraction (1971)

3.3.1 Photography and Intentionality 53

3.3.2 Locating Arnatt's Performative Gesture 57

3.3.3 Retractions and Rules of Engagement 62

3.4 The Case of Documentation: Roelof Louw's

Tape-Recorder Project (6) (1971) 68

3.4.1 Transforming Voices and Commands on Tape 71

3.4.2 The Document and the Archive $\quad 75$

3.5 Art and Violence in the Open Air:

The Activities of CAYC 80

3.5.1 Conceptual Art and Conceptualism 83

3.5.2 Inversion, Art and Violence 86

3.5.3 Closure, Enclosure and Exposure 100

3.6 Closing Remarks 103

References 104

4 The Logico-Semantics of Image and Text 111

4.1 Opening Remarks 111

4.2 Wittgenstein and Halliday $\quad 115$

4.3 The Horror of the Gallery-Goer: Keith Arnatt's
Trouser-Word Piece (1972)

4.3.1 Metaphors and Power Structures $\quad 125$

4.3.2 Dissemination and Afterlife 132

4.4 The Situation of Propositions: Victor Burgin's

Room (1970) 135

4.4.1 Defining a Place for Art 137

4.4.2 Context and Experience 139

4.4.3 Competing Voices and Their Limits 145

4.5 The Politics of Intertextuality: Juan Carlos

Romero's Swift en Swift (1970) 154

4.5.1 Printmaking and the Context of Violence 155

4.5.2 Naming Names? Superimposition as a Violent Act $\quad 160$

4.5.3 Artistic Practice and Political Mobilisation 166

4.6 Closing Remarks 171

References 173 
5 Rhetorical Operations and the Discursive

\section{Creation of Meaning}

5.1 Opening Remarks

5.2 The Dialectics of Analysis

5.3 Rhetoric and the Activity of Writing: Art \&

Language's Lecher System (1970)

184

5.3.1 Changes in Education and the Artworld

186

5.3.2 The Dissonance of Greenbergian Formalism

190

5.3.3 Movement in Four Acts

193

5.3.4 A Long-Lasting Irony?

198

5.4 Market Trends: Language, Pages and "Wordworks" on Show

5.4.1 The Page and the Art Press

5.4.2 Staging Exhibitions, Catalogues and Book Shows

5.5 Closing Remarks

References

6 Conclusions

6.1 The State of Affairs Today

References

Bibliography 


\section{List of Figures}

Fig. 1.1 Victor Burgin, Possession (1976). Duotone Lithograph. $118.9 \times 84.1 \mathrm{~cm}($ (C) Victor Burgin. Courtesy the British Council Collection)

Fig. 2.1 The relation between language and myth according to Roland Barthes (Reproduced from Barthes 1972)

Fig. 3.1 John Hilliard, 765 Paper Balls (1) (1969). Black and white photograph on board. $122 \times 122 \mathrm{~cm}$ (C) John Hilliard)

Fig. 3.2 Ian Breakwell, UNWORD 2 (1969). Performance still. 17 October 1969, ICA, London (C) Ian Breakwell and Mike Leggett. The Estate of Ian Breakwell)

Fig. 3.3 Ian Breakwell, UNWORD 2 (1969). Performance still. 17 October 1969, ICA, London (ㅇ Ian Breakwell and Mike Leggett. The Estate of Ian Breakwell)

Fig. 3.4 Ian Breakwell, UNWORD 2 (1969). Performance still. 17 October 1969, ICA, London (C) Ian Breakwell and Mike Leggett. The Estate of Ian Breakwell)

Fig. 3.5 Ian Breakwell, UNWORD 2 (1969). Performance stills. 17 October 1969, ICA, London (C) Ian Breakwell and Mike Leggett. The Estate of Ian Breakwell)

Fig. 3.6 Carlos Ginzburg, Tierra (1971) at the exhibition Arte de Sistemas I, 19 July-22 August 1971. Fibre inkjet black and white print mounted on acid free museum board. 8 photographs, $103 / 8 \times 141 / 4$ inches $(26.3 \times 36.2 \mathrm{~cm})$ each. (Detail) CAYC/Museum of Modern Art, Buenos Aires (ㄷ Carlos Ginzburg. Courtesy of the artist and Henrique Faria, New York) 
Fig. 3.7 Carlos Ginzburg, Tierra (1971) at the exhibition Arte de Sistemas I, 19 July-22 August 1971. Fibre inkjet black and white print mounted on acid free museum board. 8 photographs, $103 / 8 \times 141 / 4$ inches $(26.3 \times 36.2 \mathrm{~cm})$ each. (Detail) CAYC/Museum of Modern Art, Buenos Aires (C) Carlos Ginzburg. Courtesy of the artist and Henrique Faria, New York)

Fig. 3.8 Grupo Experiencias Estéticas (Luis Pazos, Héctor Puppo and Jorge de Luján Gutiérrez), La cultura de la felicidad (1971) at the exhibition Arte de Sistemas I, 19 July-22 August 1971. Photographic print. CAYC/Museum of Modern Art, Buenos Aires

Fig. 3.9 Grupo Experiencias Estéticas (Luis Pazos, Héctor Puppo and Jorge de Luján Gutiérrez), La cultura de la felicidad (1971) at the exhibition Arte de Sistemas I, 19 July-22 August 1971. Photographic print. CAYC/Museum of Modern Art, Buenos Aires

Fig. 3.10 Joseph Beuys, Comparación entre dos tipos de sociedades: La forma de destruir la dictadura de los partidos (1972). (Side A) Bag circulated at the exhibition Arte e Ideologia/ CAYC al aire libre, September 1972. Roberto Arlt Square, Buenos Aires. Part of Arte de Sistemas II, 21 September-8 October 1972. CAYC/Museum of Modern Art, Buenos Aires

Fig. 3.11 Joseph Beuys, Comparación entre dos tipos de sociedades: La forma de destruir la dictadura de los partidos (1972). (Side B) Bag circulated at the exhibition Arte e Ideologial CAYC al aire libre, September 1972. Roberto Arlt Square, Buenos Aires. Part of Arte de Sistemas II, 21 September-8 October 1972. CAYC/Museum of Modern Art, Buenos Aires

Fig. 3.12 Installation view of Luis Pazos, Proyecto de monumento al prisionero politico desaparecido (1972) at the exhibition Arte e Ideologia/CAYC al aire libre, September 1972. Roberto Arlt Square, Buenos Aires. Part of Arte de Sistemas II, 21 September-8 October 1972. CAYC/ Museum of Modern Art, Buenos Aires

Fig. 3.13 Installation view of Roberto Duarte Laferriere, Eduardo Leonetti, Luis Pazos and Ricardo Roux, La realidad subterránea (1972) at the exhibition Arte e Ideologial CAYC al aire libre, September 1972. Roberto Arlt Square, Buenos Aires. Part of Arte de Sistemas II, 21 September-8 October 1972. CAYC/Museum of Modern Art, Buenos Aires

Fig. 3.14 Installation view of Roberto Duarte Laferriere, Eduardo Leonetti, Luis Pazos and Ricardo Roux, La realidad 
subterránea (1972) at the exhibition Arte e Ideologial

CAYC al aire libre, September 1972. Roberto Arlt Square,

Buenos Aires. Part of Arte de Sistemas II, 21 September-8

October 1972. CAYC/Museum of Modern Art, Buenos Aires

Fig. 3.15 Installation view of Roberto Duarte Laferriere, Eduardo

Leonetti, Luis Pazos, Juan Carlos Romero and Ricardo Roux, El juego lígubre (1972) at the exhibition Arte e Ideologial CAYC al aire libre, September 1972. Roberto Arlt Square, Buenos Aires. Part of Arte de Sistemas II, 21 September-8 October 1972. CAYC/Museum of Modern Art, Buenos Aires 100

Fig. 4.1 Victor Burgin, Room (1970) (C Victor Burgin)

Fig. 4.2 Juan Carlos Romero, 4.000.000 $\mathrm{m}^{2}$ de la ciudad de Buenos Aires (1970). Text and ten photographs, $60 \times 50 \mathrm{~cm}$ each. (Detail) (C) Juan Carlos Romero. The archive of Juan Carlos Romero)

Fig. 4.3 Lawrence Weiner, Declaration of Intent (1968)

(C) Lawrence Weiner)

Fig. 4.4 Douglas Huebler, Duration Piece \# 8 (1970)

(C) Douglas Huebler)

Fig. 4.5 Juan Carlos Romero, En bomenaje a los caidos el 25/5/73

en la lucha por la liberación 1973/Homenaje a Bellocq 1943-1973 (1973). Photographic collage. $79.5 \times 69.5 \mathrm{~cm}$. Collection Museo Castagnino+macro, Rosario, Argentina

Fig. 4.6 Installation view of Juan Carlos Romero, Swift en Swift (1970) at the exhibition 3er Premio Swift de Grabado, 9-27 September 1970. Museum of Modern Art, Buenos Aires. Collection Mauro Herlitzka

Fig. 4.7 Mural detail near the entrance to the Swift meat processing plant, Berisso, La Plata, 1971. The archive of Juan Carlos Romero

Fig. 4.8 Installation view of Perla Benveniste, Eduardo Leonetti, Luis Pazos, Juan Carlos Romero and Edgardo Antonio Vigo, Proceso a nuestra realidad (1973) at the exhibition 40 Salón Premio Artistas con Acrilicopaolini, 3-19 August 1973. Museum of Modern Art, Buenos Aires

Fig. 5.1 Installation view of Art \& Language, Index 01 (1972) at Documenta 5, 30 June-8 October 1972, Kassel. Private collection, Switzerland

Fig. 5.2 Installation view of Art \& Language, Lecher System (1970) and Lecher Lines (1970) at the exhibition Idea Structures, 24 June-19 July 1970. Camden Arts Centre, London

Fig. 5.3 Installation view of the touring exhibition Artists' Bookworks (1975) (@ The British Council) 


\section{Introduction}

Conceptual art, as a historical art movement that emerged in the late 1960s and early 1970s and as a point of reference for contemporary art practices, is generally identified by its use of language. For many, it has even redefined writing as an artistic practice. But how exactly was language used, and with what aim? Equally important, how has the presence of language in a visual art context affected and changed the ways in which art is talked about, theorised and produced?

Conceptual artists utilised language in various ways: identifications, statements, instructions, commands, observations, descriptions, propositions, citations, discussions and so on. These were often combined with photographs, objects, actions or locations, and were presented as captions, postcards, sketches or essays. Among other things, words appeared on the gallery wall, in the streets, in exhibition catalogues and artists' books, and were handed out to spectators or circulated in art magazines and bulletins.

This book examines this juxtaposition of images and texts in conceptual art and specifically the cases where the visual is deliberately compared and contrasted with the textual—cases, in other words, where artists critically engage the relation between what one sees and what one reads. The terms "text" and "image" will therefore be used in their generalised categories. Taking an interdisciplinary approach, this book will show how the juxtaposition of images and texts was one of the strategies that conceptual art employed in order to expose and challenge several ideological and institutional demands placed on artistic practice. These demands included 
the production of visual and tangible objects, of objects that were unique and non-perishable, and of objects that could be easily designated as "art" and be largely qualified as vehicles of expression by their universal aesthetic value. Such demands marked the historical context of conceptual art dominated by American modernism, and remain relevant to contemporary art as a lucrative and globalised business.

Conceptual art is one of those art movements that has self-reflectively scrutinised the status of art. It advanced an institutional critique that interrogated the practices and traditions of the artworld, the gallery system and the modernist art discourse. It also advanced a socio-political critique that sought to redefine the function of art within the wider social sphere. Artists clustered under the term "conceptual" explored how meaning is materially and discursively created in the art context, and how artworks can manipulate the chain of signification and subvert meaning beyond that art context. The juxtaposition of images and texts, therefore, becomes one way of critically juxtaposing the site of visual art to other sites of cultural and social activity. It implicates the relation of art to theory and brings art's critical and social dimensions to the fore.

Another keyword associated with conceptual art is "dematerialisation". The call for a dematerialised object of art extended John Cage's "dematerialisation of intention" and advocated against the production of stable art-objects exclusively destined for gallery display. In their seminal article The dematerialization of art, Lucy Lippard and John Chandler (1968) detect a tendency in the artistic production of their time to move away from producing finite objects and from object-making in general. They moreover identify within this tendency the potential to challenge the spectatorial expectations of the gallery visitors and engage them instead as participants; and to challenge the traditional responses to art, the materials typically associated with it and the critic's role in evaluating the work's formal or emotive impact.

\subsection{Why LANGUAGE?}

But the question remains: Why use language? Language gives particular sociability to art's critical gesture since it is the means of interpersonal communication. The use of language also capacitates an engagement with the context of artistic production. This includes how an artwork is produced, received and understood, as well as the place that it occupies culturally, as part of a tradition of production and in society more generally. 
In short, it foregrounds how and what art communicates. In previous artistic movements such as the Russian avant-garde, the dialogue between the visual and the textual derived from the reconceptualisation of art as an active agent in social change (Grey 1986). For Futurism, Dada and Cubism, an experimental approach to visual and poetic representation was supported by typographical innovation (Drucker 1994). In the case of conceptual art, the historical context of the 1960s and 1970s was marked by American modernism, the growth of the art market and cultural imperialism, socio-political shifts at a global scale and media propaganda, as well as reconsiderations of the role of discourse, language and culture in capitalist societies more broadly.

American modernism and in particular the formalism of Clement Greenberg became the most theorised and predominant model for artistic production. It was materially supported and discursively promoted by wealthy metropolitan museums with large-scale exhibitions such as New York Painting and Sculpture 1940-1970 (16 October 1969-1 February 1970, the Metropolitan Museum of Art), which presented more than 400 works. It also enjoyed corporate funding such as that from the Guggenheim, the Rockefeller and the Ford Foundations, which was explicitly aligned to their political programmes. It is to this conjuncture of artistic production, marketing and discourse that critically engaged conceptual art brought attention. In turn, that this conjuncture remains under scrutiny is one of conceptual art's contributions to contemporary art and criticism.

In a plethora of texts, modernist art discourse defined the experience of art as universal and unmediated, a private affair of contemplation away from any social or political concerns. The production of modernist narratives exponentially increased during the Cold War. At the same time that anti-imperialist and revolutionary struggles throughout the world negated the self-declared dominance of capitalism and workers', students' and social rights' movements rejected its institutions, American modernism functioned as a placeholder for bourgeois values and capitalist ideology. It became instrumental in the United States' programme of cultural colonisation-in particular abstract expressionism, which was celebrated as a truly American art form and a triumph over politically committed art (Cockcroft 1974). In Latin America, American modernism occupied the artworld through what was advanced as the "internationalisation of style" yet took place in a social context characterised by imperialist exploitation, US interventionism, consecutive military dictatorships, media propaganda and fierce social repression. 
In this historical context, many conceptual art practices incorporated or emerged as a critique of American modernism and its associated ideas regarding the autonomous and disinterested artwork, the uniqueness of the artistic genius and the private interests of art. They challenged the hierarchical and ideological divisions between the artist as the producer, the critic as the qualifying expert and the viewer as the consumer. They opposed the isolation of art from other social activities and political concerns, and criticised capitalist society and consumerist culture. This was done by using language but also by utilising the media and the press, staging public interventions, carrying out sociological research and developing activities outside the official gallery networks. Indeed, conceptual art can be seen as modernism's nervous breakdown (Baldwin and Ramsden 1997, 32).

Notwithstanding the focus of this book on the critical interests of conceptual art, it should not be assumed that every conceptual artist was interested in advancing an institutional or a socio-political critique. Using language was often simply a matter of following the trend, or a marketing strategy that both artists and galleries employed because of the low costs involved in the reproduction and dissemination of text-based works. It is important therefore to emphasise the difference between a critical use of language and a symptomatic proliferation of printed matter that stated nothing further than the obvious. A further reason for the increase of textual production has to do with documentation. Photographs, project descriptions, letters, sketches, notes and instructions were used as a confirmation of an absent work or idea after the event. These attracted the interest of collectors and institutions who became instrumental in conferring to such paraphernalia of the creative process the status of art and a price tag to match.

Another historical factor that conditioned the use of language in conceptual art was the state of affairs of scholarship. While the modernist art discourse dominated the artworld, analytic philosophy from the mid 1950s onwards refuted the accountability of language for universal truth and demanded deeper attention to its use. This method of analysis revealed logical problems in the expression theory of art that held it to be a universal vehicle of emotions, and became the basis for a systemic and culturally specific understanding of the artworld (Danto, Dickie). In addition, the incorporation of Marxist dialectics in the analysis of society and culture exposed the workings of ideology, helped conceptualise the processes of mystification and alienation, and demonstrated how narratives structure 
social life (Barthes, Althusser, Foucault). It particularly showed how, in consumerist cultures where the media and the official cultural outlets propagate whatever aspect of reality better suits the financial and political interests of their stake-holders, the public space of language becomes subverted. By the end of the 1970s, the newly established discourse analysis and visual culture studies underlined the social and political dimensions of both language and art as sites of ideological conflict; and a social history of art developed with influences from Marxism (Hauser, Clark), and later feminist critique and critical theory. These theoretical developments contested the ideological investments made in the object of art as well as the function of discourse in normalising the experience of art.

As such, the historical context of conceptual art was, in general, characterised by reconsiderations and reevaluations of processes across the cultural and social spheres. In turn, conceptual art instituted a critical enquiry into the production and function of art. This causes certain difficulties in discussing conceptual art. Some of its propositions, for example that other artistic means beyond painting and sculpture are eligible, may now appear self-evident. Returning to conceptual art is important, however, since it initiated crucial debates, still unresolved today, regarding the role of institutions and the market, the relation between theory and practice, the relation between art and politics, and the hegemonic practices of art history.

Let us return to the starting point of this book-conceptual art's critical engagement with art and society through the juxtaposition of images and texts. Too often, conceptual artworks are considered to have failed to suppress the aesthetic experience of art or to be authoritarian versions of the ready-made (Krauss, Buchloh, de Duve). This may be relevant to works that did not aim to address or that did not succeed in interrogating the support systems which made them possible. As a result, they may have dematerialised their object (in the sense of lacking formal restrictions of execution) but their propositions as works of art could still be absorbed by the Greenbergian paradigm of a formalised, introvert and ahistorical art. At the same time, many contemporary art practices seek to specify and call upon a "strong" conceptual art tradition of prioritising the "idea". This enables them to use their own relation to discourse as a form of legitimation and to justify their celebrated self-referential status (Osborne 1997).

By these accounts, the position of conceptual art seems paradoxical, having been put to use in serving different, and often competing, interests. Yet understanding how artistic production is wrapped in a discursive field is another one of conceptual art's most important contributions. 
As for the general conception that conceptual art prioritised the idea behind the work, this is only one side of the story. To be exact, conceptual art demonstrated the dependence of art, its experience and meaning on context. It specifically showed that the licence to claim that one is only interested in a something (an idea, a significant form, a universal aesthetics) and that nothing else matters can only be supported within particular discursive and ideological frameworks. In the case of conceptual art, the most predominant of such frameworks are modernism and its ideological investments in the aesthetic; the commodification of art and curatorial anxieties in classifying art-objects; and (cultural) imperialism. It is these frameworks that critically engaged conceptual art practices sought to expose and challenge.

In order to do so, works from this period dislocated and recontextualised not only different types of objects but also modes of production and systems of interpretation. They drew attention to the habitual ways of producing, looking at and theorising art, and contested the hierarchies of value and meaning that operate across the space of art as a social space. In search of resources and alternative frames of reference, artists turned to subjects that were considered to be beyond the scope and established interests of artistic practice such as philosophy of language, logic, mathematical and semiotic systems, official discourse, legal speak, the everyday, mass media and advertisement. They juxtaposed seemingly incompatible discourses in order to generate instances of critique and reflection on the frameworks of interpretation and evaluation, and advanced a method of critical looking that could be transposed from the context of art to other spheres of activity and vice versa.

To be able to sustain this critique, the conceptual artwork remains provisional, logically inconclusive or in oscillation between the obvious and the absurd. This creates a discontinuity of meaning that confronts the viewer and can only be resolved by recognising both the work's claims and the frameworks that determine how it is produced and received. Consider, for example, Victor Burgin's work Possession (1976). Produced to accompany an exhibition at the Fruitmarket Gallery, Edinburgh, it was reprinted in 500 copies and fly-posted across Newcastle (Fig. 1.1). This work draws external resources in order to communicate its critique and exemplifies what I will call the loan rhetoric of conceptual art (I return to this in Chapter 5). Utilising distinct systems of reference, discourses and vocabularies, this loan rhetoric becomes a means to critically situate artistic practice within the material and discursive contexts that make it possible and a means to interrogate the practices which operate within these contexts. 


\section{What does possession mean to you?}

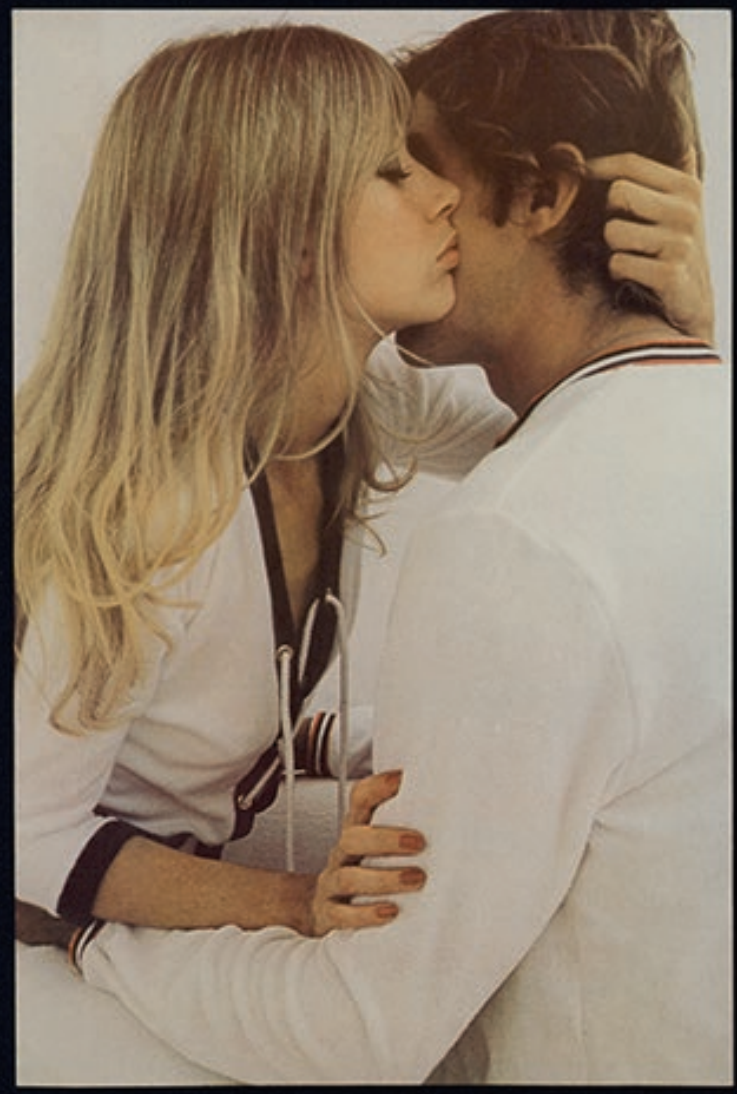

\section{$7 \%$ of our population own $84 \%$ of our wealth}

Fig. 1.1 Victor Burgin, Possession (1976). Duotone Lithograph. $118.9 \times 84.1 \mathrm{~cm}$ (C) Victor Burgin. Courtesy the British Council Collection) 
Image and text juxtapositions, therefore, do not only provide a route to consider the role of language. More crucially, they become a way to engage the social function of art.

\subsection{Aвout This Book}

This book offers an interdisciplinary study of image and text juxtapositions as they were used critically in conceptual art. It examines the production and reception of works in the late 1960s and the 1970s, and draws its main examples from the historically established triangle of exchanges across the United Kingdom, the US and Argentina. It specifies how artworks communicate in context and evaluates their critical potential to challenge the frameworks that determine how art is produced, theorised and experienced. It proposes three methods of analysis that consider the work's performative gesture, its logico-semantic relations and the rhetorical operations in the discursive creation of meaning. Resources are drawn from art history and theory, philosophy, discourse analysis, literary criticism and social semiotics.

These theoretical frameworks offer a methodologically well-structured mode of analysis of the object in question both at the time of the event and from our current historical standpoint. They are epistemologically efficient in acknowledging the different contexts of the creative act (the material, discursive, institutional and historical context), and in specifying how the act functions within and impacts these contexts. They specifically attend to a work's material presence, interaction between different elements and contextual relevance. Analytic philosophy and speech act theory were historically available and of interest to many conceptual artists, and the concept of the performative has been widely applied in art history, art criticism and image and text studies. For reasons of methodological clarity, this approach is not used on artworks that themselves cite speech act theory. Logico-semantics examines the process of meaning-making in context, the frameworks of interpretation and, like speech act theory, the conditions of communication. It was developed in the late 1970s and offers a systematic approach to re-semiotisation and multimodality. Rhetoric and how discourse can be manipulated formed another point of historical interest for theorists and conceptual artists, and is a method of analysis particularly suitable for works that contain longer textual components. At the same time, it offers a reflective mode of engaging with the telling and re-telling of the story of conceptual art-a process of constant reconfiguration of status and value in which this book also partakes. 
One of the central premises of this book, which it takes from discourse analysis and introduces to the examination of visual culture, is that meaning is socially created. Specifically, meaning-making is a shared activity within interpretive communities and for both texts and images, meaning is not a priori but determined by function and use. The same goes for their value. There is no one-to-one correspondence between truth and language or nature and art. Signs have no fixed value, but they do not freely float about, either. Rather, meaning is formulated by discursive operations that set the standards of interpretation and evaluation.

By juxtaposing texts with images, conceptual art caused shifts in the regimes of reading and viewing. Works negotiated their own particular configuration against the assumptions and value systems that they sought to challenge in terms of representation (a task traditionally reserved for art), interpretation (a task traditionally reserved for criticism) and the institutional frameworks that supported them. Transposing competing voices and attitudes to the art gallery or a public site can expose the limits and limitations of the discourses that operate in and define these sites. It can also create a space wherein both the subject and the object can be dialectically negotiated - a particular site of engagement, which disables the presumed autonomous status of the referent and invites critical reflection.

At the same time, one must keep in mind how bestowing objects with meaning and value as art is a historical practice. To understand something (an image, a text, an artistic gesture) is to place it within an interpretive context and set it in dialogue with common practices and prevailing ideologies from that context. Making sense is a process that operates within supporting frameworks and requires one to evaluate the relevant, and therefore meaningful, associations that structure communication in its historical development. To put it differently, things are always already read and viewed in context wherein traditional and habitual regimes guide how these are recognised and understood. For this reason, in order to engage the frame of reference one must also engage the adequate and relevant systems of signification and the rules of use.

With this in mind, this book will demonstrate how conceptual art opens up and critically engages the space of art as a social space- a space of social interaction, communication and responsibility. The context in which the case studies will be discussed refers to socio-political developments, key exhibitions and their reception, and theoretical discussions by artists and critics on the nature of art, its classification, evaluation and role in society, the use of language and the function of institutions. In considering 
the effects of display and the politics of the gallery space, this book will also scrutinise the archival material it uses. Special attention will be given to how the press fulfils particular ideological and social functions in its mediation of reality.

In order to situate the critical interest of conceptual art as a movement, examples are taken from different geographical and socio-political sites. This demonstrates how different practices advance their institutional and socio-political critique, and how they relate to their context and to each other. It also demonstrates the reapplicability of the methods of analysis. As noted above, the concern of this book is cases where the textual is brought into critical dialogue with the visual, and the terms "image" and "text" will be used to refer to photographs, installations, accompanying texts, explanatory notes, statements, propositions and essays on display or in published form. By the same token, "juxtaposition" refers to the visual presence of language in the art gallery context as well as to the use of languages, discourses and rhetorics not traditionally associated with art.

Chapter 2 offers an overview of some of the main conceptual and methodological parallels made between art and language such as expression theory, analytic philosophy, the institutional theory of art, semiotics, discourse analysis and multimodality. It outlines key concepts regarding the category of art, theorisations of the system of art and modes of engaging with the object of art. It aims to bring the wider field of image and text studies into dialogue with art history and theory, highlights the relationship between image and text in its historical development within cultural production, and demonstrates how they participate in communication as a social process. By presenting the wider context of scholarship on the relation between art and language, this chapter establishes the interdisciplinary interest of the analysis to follow. This overview also helps trace the origin of many of the debates that resurface in the discussion of conceptual art and of image and text relations. In other words, Chapter 2 helps frame the frameworks of analysis.

Chapter 3 discusses speech act theory and the concept of the "performative" in relation to Keith Arnatt's Art as an Act of Retraction (1971, London), Roelof Louw's Tape-Recorder Project (6) (1971, London and New York) and the exhibitions Arte de Sistemas I [Art of Systems I] (1971, Buenos Aires) and Arte e Ideologia/CAYC al aire libre [Art and Ideology/ CAYC in the open air] (1972, Buenos Aires) organised by the Centre of Art and Communication (CAYC). It specifies how images and texts operate in different physical environments as well as in different discursive 
contexts. It considers the use of photography and installation in staging an event and in inverting the mediation of reality, the effects of documentation, the role of the archive and institutional discourse, and the relation between art, violence and political mobilisation. Examining the performative gesture of art demonstrates how the creation of meaning is a social and shared activity, and allows us to determine how artworks function and communicate in context. Chapter 3 also reflects on the binary distinction between conceptual art and conceptualism. It considers the historical and discursive formulation of these terms and their nuances as proper names with reference to the centre/periphery debate and to hegemonic practices within art history.

Another way of examining how an artwork creates and manipulates the conditions of its communication is to analyse its logico-semantic relations. These are discussed in Chapter 4. A logico-semantic analysis determines the relations between signs within linguistic structures and the relations between signs and extra-linguistic objects and discourses - that is, the semantic relations-in the meaning-making process. Rather than directly applying the logico-semantic relations that M.A.K. Halliday established between linguistic clauses in his development of functional grammar, this chapter takes a wider approach. Based on Ludwig Wittgenstein's attention to the relation between propositions and the world and Halliday's consideration of language as a social semiotic system, this chapter develops a methodological framework for examining the logico-semantic relations between a work's textual and visual components, as well as between propositional content and visual presentation.

As case studies, Chapter 4 examines Arnatt's Trouser-Word Piece (1972, London), Victor Burgin's Room (1970, London and Buenos Aires) and Juan Carlos Romero's Swift en Swift (1970, Buenos Aires). Even though these artists and their works operated in different geographical and material sites, they were historically in dialogue and came in contact through a common network of critics and galleries. These works disturb the habitual ways of reading and viewing art and interrogate its interpretive frameworks. They draw attention to institutional legitimation, the social context of communication, aesthetic apprehension and social violence. This chapter also discusses the effects of the work's transposition to different geographical sites and from the gallery wall to the catalogue page, as well as the difference between a tautological and a critically engaged practice. This difference, together with how the use of language was a prominent topic of discussion, is illustrated in the examination of Joseph Kosuth's Art 
after philosophy and Burgin's Situational aesthetics, both published in the same issue of Studio International in 1969. Chapter 4 continues the discussion on the relation between art and politics, the workings of ideology and media propaganda. It also makes an important distinction between the particular aesthetic investments in art that conceptual art sought to challenge and how the work's own material presence and textual stylistics contribute to its meaning. This line of enquiry is further developed in Chapter 5.

Chapter 5 scrutinises the discursive creation of meaning and argues that conceptual art did not only engage art's aesthetic but also its rhetoric. This refers to the rhetoric used when talking about art as well as to the rhetorical operations performed by the work itself. This chapter examines discourse in terms of the institution of art, the writing of history and the normalisation of knowledge; and determines the rhetorical shifts that a work performs in order to destabilise different frames of reference. It closely reads Greenbergian formalism vis-à-vis Art \& Language's Lecher System (1970) which, in varying forms, appeared on gallery display and in exhibition catalogues, art magazines and book publications. Typical to Art \& Language's practice, the boundaries of the object in question are not clear. Drawing on this and borrowing from Paul de Man's discussion of rhetoric and irony, Chapter 5 locates the loan rhetoric of conceptual art. This will be specified as a strategy of manipulating different voices and languages in order to challenge the designated context for art. This causes shifts in meaning that in turn expose the conventional framings of art-an intention that is further incorporated into the mode of the work's production-and reframe the relation between theory and practice.

The examination of a work's loan rhetoric enables our understanding of the dialectical relationship between the work and the world. It focuses on how a work negotiates a polyphony of voices in order to comprise its own, and offers a way to approach a practice that self-reflectively engages the frameworks that define it and which it seeks to contest. Crucially however, this process does not end at the work but becomes part of the telling and re-telling of its story. If conceptual art has changed the ways we do and talk about art, this attention to discourse is its legacy in terms of contribution to theory. The second part of Chapter 5 reviews different uses of the page, the function of the art press and shifting exhibition trends. The latter range from exhibitions that critically engaged their location and catalogue, such as those organised by Lucy Lippard and Seth Siegelaub, to commercial shows and survey exhibitions. In doing so, this chapter charts how a market for word-related 
objects emerged by the end of the 1970s. This effectively institutionalised conceptual art and rematerialised its object.

Chapter 6, Conclusions, summarises the contribution of conceptual art to artistic practice and art theory, and reiterates art's critical potential. Conceptual art demonstrated a mode of interrogating the systems of apprehension, classification and evaluation by working around the frame of reference, and opened up the space of art as a social space. Image and text juxtaposition is one such strategy for implicating and challenging multiple voices, activities and discourses from both the artworld and the wider social context. While this book proposes three frameworks for analysing the use of juxtaposition in conceptual art, it hopes to offer a comprehensive methodology that can be applied in other examples from art and visual culture. Following conceptual art's institutional and socio-political critique, one such instance is what has been identified, in contemporary art, as social practice. Conceptual art also problematised the object of art in relation to theory and drew to the surface the implications of writing about art and "doing" art history. This book becomes an additional discursive framework that situates the conceptual artwork. One cannot ignore how it participates in processes that locate the work and what is considered to be the work by choosing adequate frames of reference; nor how an ever-expanding market and proliferating (albeit often competing) art historiographical narratives constantly reframe and rewrite the story of conceptual art.

If there is discontinuity between the voice of the present interdisciplinary analysis and the accustomed frameworks for treating conceptual art, this can help play out the dissonance that conceptual art practices created by bringing together a polyphony of voices and methods. Perhaps interdisciplinarity, like juxtaposition, is not possible unless one is willing to critically suspend the institutional separations that make it possible.

This book will not do a number of things. It will not attempt to define "conceptual art" as a singular art movement, nor will it profess to offer an exhaustive study of how images and texts have been used by conceptual or other artists. But it will locate the contextual relevance and critical potential of selected case studies and consider the space that they occupy historically and discursively. Equally, it will not try to defend the presence or absence of any aesthetic impulse. Rather, it will discuss how historical value systems determine what is to be understood as the nature and scope of art and the vested interests that isolate artistic production from other social, political and economic processes. 
In recent years, there has been a tendency to celebrate the fluidity of meaning. At the same time, however, artworks rely upon discursive operations beyond their body in order to convey and legitimise their claims, and an ever-expanding art market very confidently reconfigures their material status and value. If conceptual art permanently asks the question "What is art?", it also draws attention to how the whereabouts of the work can be located in the frameworks that support it. So what is the difference? To ask how one can know the dancer from the dance is an enabling question.

\section{REFERENCES}

Baldwin, Michael, and Mel Ramsden. 1997. Memories of the medicine show. ArtLanguage, New Series 2: 32-49.

Cockcroft, Eva. 1974. Abstract expressionism, weapon of the cold war. Artforum 12(10): 39-41.

Drucker, Johanna. 1994. The visible word: Experimental typography and modern art, 1909-1923. Chicago: University of Chicago Press.

Gray, Camilla. 1986. The Russian experiment in art: 1863-1922, rev. ed. London: Thames and Hudson.

Lippard, Lucy, and John Chandler. 1968. The dematerialization of art. Art International 12(2): 31-36.

Osborne, Peter. 1997. Conference discussion. Healthy alienation: Conceptualism and the new British art, the Tate Gallery, London, June 13. Audio recording available from the Tate Library TAV 1781A. 